\title{
HUBUNGAN SANITASI FISIK RUMAH DENGAN KEJADIAN INFEKSI SALURAN PERNAPASAN AKUT PADA BALITA DI PUSKESMAS KARO KELURAHAN KARO PEMATANGSIANTAR
}

\author{
Samuel Marganda Halomoan Manalu, Cindy Avrilta Sembiring \\ Institut Kesehatan Deli Husada Delitua \\ e-mail: samuelmarganda@yahoo.co.id
}

\begin{abstract}
:
The objective of this research is to find out the environment health housing that influencing the numbers of upper respiratory tract infection incidence in children under 5 years old in puskesmas karo. The research was 67 children under 5 years old. Result of this study showed the upper respiratory tract infection incidence in children under 5 years old was 52,2 percent. Over crowed of the room, type of wall and room ventilation had the significant influence to the upper respiratory tract infection incidence of the children under 5 years.
\end{abstract}

Keywords: physical sanitation of the house, upper respiratory trac infection incidence.

\section{PENDAHULUAN}

Infeksi Saluran Pernapasan Akut atau ISPA masih menjadi permasalahan di Indonesia. Hal ini terlihat dari proporsi kematian yang disebabkan oleh ISPA mencakup $20-30 \%$ dan seluruh kematian adalah anak balita. Hasil survei demografi dan kesehatan Indonesia Tahun 2019 memperlihatkan prevalensi ISPA pada anak usia $<1$ tahun sebesar 38,7 \% dan 42,2 \% pada usia 1-4 tahun.

Berdasarkan laporan Puskesmas Karo Kelurahan Karo, dalam 3 tahun terakhir, ISPA menduduki peringkat pertama pada 10 penyakit terbesar dengan jumlah kasus sebanyak 755 pada tahun 2016, pada tahun 2017 sebesar 348 kasus, dan 379 kasus pada tahun 2018.

ISPA merupakan penyakit yang paling banyak diderita oleh anak-anak, salah satu penyebabnya adalah sanitasi fisik rumah yang tidak memenuhi syarat kesehatan. Sumber pencemaran dari lingkungan dalam rumah seperti kepadatan rumah, jenis dinding dan ventilasi rumah yang kondisi fisik rumahnya tidak memenuhi syarat.

Pencemaran udara di lingkungan rumah akan merusak mekanisme pertahanan paru dan mempermudah timbulnya gangguan pada pernapasan. Faktor-faktor yang menyebabkan turunnya kualitas udara disebabkan oleh sanitasi fisik rumah yang tidak memenuhi syarat baik yang berasal dari dalam atau luar rumah.

Sehubungan dengan hal ini, saya ingin melakukan penelitian yang bertujuan untuk mengetahui hubungan sanitasi fisik rumah dengan kejadian infeksi saluran pernapasan akut (ISPA) pada balita di Puskesmas Karo Kelurahan Karo.

\section{METODE}

Jenis penelitian ini adalah observasional dengan desain cross sectional. Penelitian ini dilakukan pada bulan Mei-Juni 2018 di Kelurahan Karo Pematangsiantar tahun 2019. Populasi pada penelitian ini adalah seluruh balita 
yang bertempat tinggal di Kelurahan Karo sebanyak 200 balita. Sampel pada penelitian ini adalah balita yang bertempat tinggal di Kelurahan Karo. Pengambilan sampel dengan cara mendatangi rumah ibu sebagai responden yang memiliki balita dengan kriteria inklusi bersedia di wawancarai. Besar sampel pada penilitian ini adalah 67 balita yang diperoleh dari hasil perhitungan besar sampel menggunakan rumus slovin.

Teknik pengambilan sampel menggunakan teknik purposive sampling. Variabel dependen adalah kejadian ISPA pada Balita di Puskesmas Karo kelurahan karo sedangkan variabel inpedenden meliputi kepadatan rumah, jenis dinding dan ventilasi rumah. Kejadian pada ispa dilakukan dengan wawancara kepada ibu balita menggunakan keusioner dibantu oleh kader puskesmas karo dan hasil yang ditentukan 2 kategori yaitu ISPA dan tidak ISPA. Sedangkan untuk mengukur sanitasi fisik rumah menggunakan metode wawancara dan kuesioner. Nilai hasil pengukuran sanitasi fisik rumah kemudian dibandingkan dengan standar peraturan terkait dan kategori menjadi 2 (memenuhi syarat dan tidak memenuhi syarat).Data diolah dengan menggunakan uji chi-square dengan $a=0,05$. Uji chi-square digunakan untuk analisis bivariat antara variabel sanitasi fisik rumah dengan kejadian ISPA pada balita, sehingga diketahui faktor apa saja yang mempengaruhi kejadi ISPA pada Balita di Puskesmas Karo Pematangsiantar.

\section{HASIL DAN PEMBAHASAN}

\section{Kejadian ISPA pada Balita}

Balita di Puskesmas Karo mengalami ISPA sebanyak 55,2 \% dan sisanya 47,8 $\%$ tidak ISPA sebagaimana ditunjukkan dalam tabel berikut.
Tabel 1. Distribusi Kejadian Infeksi Saluran Pernapasan Akut di Puskesmas Karo

\begin{tabular}{ccc}
\hline $\begin{array}{c}\text { Kejadian } \\
\text { ISPA }\end{array}$ & $\mathrm{F}$ & $\begin{array}{c}\text { Presentase } \\
\%\end{array}$ \\
\hline Tidak ISPA & 32 & 47,8 \\
ISPA & 35 & 52,2 \\
Total & 67 & 100 \\
\hline
\end{tabular}

Berdasarkan hasil penelitian diketahui bahwa balita di puskesmas karo kelurahan karo dengan mayoritas gejala ISPA disertai dengan gejala demam, batuk dan pilek.

\section{Sanitasi Fisik Rumah dan Kepadatan Rumah}

Berdasarkan tabel diatas dapat dilihat bahwa hubungan kepadatan rumah dengan kejadian ISPA pada balita yang tidak memenuhi syarat sebanyak 24 orang $(75,0 \%)$ sedangkan sebanyak 8 orang $(25,0 \%)$ memenuhi syarat dan balita yang tidak mengalami ISPA pada rumah yang memenuhi syarat sebanyak 19 orang $(54,3 \%)$ dan sebanyak 16 orang $(45,7 \%)$ tidak memenuhi syarat.

Tabel 2. Distribusi Kepadatan Rumah dengan Kejadian ISPA di Puskesmas Karo.

\begin{tabular}{ccccc}
\hline $\begin{array}{c}\text { Kepada } \\
\text { tan } \\
\text { rumah }\end{array}$ & \multicolumn{2}{c}{ Kejadian } & & \\
& ISPA pada & Total & P \\
Ya & Tdk & & \\
\hline Tidak & 24 & 16 & 40 & 0,015 \\
Padat & 8 & 19 & 27 & \\
\hline Total & 32 & 35 & 67 & \\
\hline
\end{tabular}

Dari hasil penelitian yang dilakukan dengan 67 responden diperoleh hasil hubungan kepadatan rumah dengan kejadian ISPA pada balita yang tidak memenuhi syarat sebanyak 24 orang $(75,0 \%)$ sedangkan 8 orang $(25,0 \%)$ yang memenuhi syarat dan pada balita yang tidak mengalami ISPA rumah yang memenuhi syarat sebanyak 19 orang $(54,3 \%)$ dan 16 orang $(45,7 \%)$ yang tidak memenuhi syarat. Hal ini disebabkan oleh banyaknya balita yang 
tinggal di rumah yang memiliki kepadatan rumah yang tidak sesuai dengan luas lantai rumah bila dibandingkan dengan jumlah balita yang tinggal di rumah yang kepadatan rumahnya sesuai dengan luas lantai rumah, balita yang tinggal di rumah yang kepadatan rumahnya tidak memenuhi syarat berisiko menderita ISPA bila dibandingkan dengan balita yang menetap di rumah yang kepadatan rumahnya memenuhi syarat.

Berdasarkan uji statistic antara Kepadatan rumah dengan Kejadian ISPA pada Balita yang menggunakan uji ChiSquare menunjukkan bahwa $\mathrm{p}$ value ( $0,015)<a(0,05)$. Maka dengan kata lain Ha diterima dan Ho ditolak, hal ini menunjukkan adanya hubungan yang signifikan antara Kepadatan Rumah dengan Kejadian ISPA pada Balita di Puskesmas Karo Kelurahan Karo Pematangsiantar Tahun 2019. Hal ini disebabkan oleh banyaknya balita yang tinggal dirumah yang memiliki kepadatan rumah yang tidak sesuai standar rumah sehat.

Balita yang tinggal dirumah yang kepadatan rumahnya tidak memenuhi syarat berisiko menderita ISPA dibandingkan dengan balita yang menetap dirumah yang kepadatan rumah nya memenuhi syarat. Kepadatan rumah yang tidak memenuhi syarat,akan menyebabkan kelembapan ruangan tinggi sehingga bibit penyakit dapat berkembang biak dengan baik dan mempermudah terjadinya penularan penyakit baik secara langsung maupun tidak langsung. Jumlah penghuni rumah yang padat menyebabkan berkurangnya ruang bagi setiap penghuni,sehingga kontak antara penghuni lebih sering dan lebih lama.akibatnya bila ada penderita infeksi saluran pernapasan akut (ISPA) didalam rumah akan lebih mudah terjadi penularan ke penghuni lainnya.

\section{Jenis Dinding Rumah}

Tabel 3. Distribusi dinding rumah

dengan kejadian ISPA di Puskesmas

Karo

\begin{tabular}{lcccc}
\hline \multirow{2}{*}{$\begin{array}{l}\text { Dinding } \\
\text { rumah }\end{array}$} & \multicolumn{2}{c}{ Kejadian } & & \\
& ISPA padita & Total & P \\
& Ya & Tdk & & \\
\hline Tidak & 19 & 25 & 44 & 0,011 \\
Baik & 13 & 10 & 23 & \\
\hline Total & 32 & 35 & 67 & \\
\hline
\end{tabular}

Berdasarkan hasil penelitian yang dilakukan dengan 67 responden diperoleh hasil bahwa hubungan jenis dinding rumah dengan kejadian ISPA pada balita yang memenuhi syarat (MS) sebanyak 19 orang $(59,3 \%)$ sedangkan yang tidak memenuhi syarat (TMS) sebanyak 13 orang $(40,6 \%)$ dan pada balita yang tidak mengalami ISPA rumah yang tidak memenuhi syarat sebanyak 25 orang $(71,4 \%)$ dan yang memenuhi syarat sebanyak 10 orang (28,6\%). Berdasarkan uji statistik yang dilakukan terhadap jenis dinding rumah dengan Kejadian ISPA pada Balita menggunakan uji ChiSquare menunjukkan $\mathrm{p}$ value $=0,011<\mathrm{a}=$ 0,05 .

Artinya terdapat hubungan yang signifikan antara hubungan Jenis Dinding Rumah dengan Kejadian ISPA pada Balita di Puskesmas Karo Kelurahan Karo Pematangsiantar tahun 2019. Berdasarkan (Kepmenkes RI, 1999) dinding rumah yang memenuhi syarat adalah dinding yang dilengkapi dengan ventilasi dan sirkulasi udara, kedap air dan mudah dibersihkan. Pada penelitian ini dinding yang memenuhi syarat adalah yang terbuat dari tembok plester dan dalam kondisi bersih, sedangkan dinding yang tidak memenuhi syarat adalah dinding yang terbuat dari bambu/bilik, papan (triplek), atau tembok non-plester, serta tembok plester dalam keadaan kotor. Hasil penelitian menunjukkan bahwa dinding rumah memiliki hubungan 
yang signifikan dengan kejadian ISPA pada Balita.

Hal ini disebabkan karena balita tinggal dirumah dengan jenis dinding yang tidak memenuhi syarat (bambu, papan kayu, tembok non plester, tembok plester dalam keadaan kotor) dinding yang terbuat dari bambu/bilik dan papan merupakan jenis dinding yang tidak kedap air dan sulit dibersihkan sehingga memungkinkan polutan dan bahan iritan masuk kedalam rumah. Tembok nonplester dianggap tidak memenuhi syarat karena meskipun terbuat dari bahan yang kedap air, tetapi tembok jenis ini memiliki permukaan dinding yang tidak permanen, tidak halus, tidak rata sehingga sulit dibersihkan dari debu dan kotoran lain yang menempel. Tembok non-plester juga dapat menyebabkan kelembapan ruangan menjadi tinggi dan menimbulkan debu. Jenis dinding rumah yang tidak memenuhi syarat sanitasi rumah lebih rentan membawa debu-debu kedalam rumah sehingga dapat membahayakan peghuni rumah bila terhirup dan dapat lebih beresiko terkena penyakit infeksi saluran pernapasan akut.

\section{Ventilasi Rumah}

Tabel 4. Distribusi Ventilasi Rumah dengan Kejadian ISPA di Puskesmas Karo.

\begin{tabular}{ccccc}
\hline \multirow{2}{*}{$\begin{array}{c}\text { Ventila } \\
\text { si }\end{array}$} & \multicolumn{2}{c}{ Kejadian } & & \\
ISPA pada & Total & P \\
rumah & Balita & & Value \\
& Ya & Tdk & & \\
\hline Tidak & 25 & 13 & 38 & \multirow{2}{*}{0,001} \\
Kokoh & 7 & 22 & 29 & \\
\hline Total & 32 & 35 & 67 & \\
\hline
\end{tabular}

Berdasarkan penelitian yang dilakukan dengan 67 responden diperoleh hasil hubungan Ventilasi Rumah dengan kejadian ISPA pada balita yang tidak memenuhi syarat (TMS) sebanyak 25 orang $(78,1 \%)$ sedangkan 7 orang (21,9\%) yang memenuhi syarat (MS) dan pada balita yang tidak mengalami ISPA rumah yang memenuhi syarat sebanyak
22 orang $(62,9 \%)$ dan 13 orang $(37,1 \%)$ yang tidak memenuhi syarat. Berdasarkan hasil uji statistik antara ventilasi rumah dengan Kejadian ISPA pada Balita yang menggunakan uji ChiSquare menunjukkan bahwa $\mathrm{p}$ value $=$ $0,001<a=0,05$.

Artinya terdapat hubungan yang signifikan antara hubungan Ventilasi Rumah dengan Kejadian ISPA pada Balita di Puskesmas Karo Kelurahan Karo Pematangsiantar tahun 2019. Ventilasi adalah jalan masuknya udara segar kedalam ruangan atau rumah dan jalan keluar bagi udara kotor. Selain itu,ventilasi yang buruk dapat menyebabkan asap dan udaara kotor terperangkap didalam rumah, serta dapat menahan kelembapan didalam rumah yang menibulkan kelembapan dan jamur. Keberadaan ventilasi dalam rumah bermanfaat bagi sirkulasi pergantian udara dalam rumah serta mengurangi kelembaban.

Ventilasi yang baik membuat udara leluasa bergerak sehingga udara dapat terus berganti.selain itu cahaya matahari yang mengandung sinar ultraviolet dapat membunuh kuman penyakit dalam rumah terutama penyakit yang ditularkan melalui udara . Ventilasi yang buruk menyebabkan aliran udara tidak lancar ,sehingga bakteri patogen sulit untuk keluar karena tidak ada aliran udara yang cukup untuk membawa bakteri keluar rumah. Hal ini mempermudah penularan ISPA karena prinsipnya kuman ISPA ditularkan oleh penderita ke orang lain melalui udara pernapasan dan percikan ludah penderita. Kuman ISPA yang ada diudara terisap oleh pejamu baru dan masuk kesaluran pernapasan. Kuman menyebar keseluruh tubuh apalagi bila orang yang terinfeksi ini rentan maka ia akan terkena ISPA terutama Balita yang cenderung memiliki sistem kekebalan tubuh yang lemah. 


\section{KESIMPULAN}

Berdasarkan hasil penelitian tentang Hubungan Sanitasi Fisik Rumah dengan Kejadian Infeksi Saluran Pernapasan Akut (ISPA) Pada Balita di Puskesmas Karo Kelurahan Karo Pematangsiantar Tahun 2019 maka dapat ditarik kesimpulan sebagai berikut Ada Hubungan antara Kepadatan Rumah, Jenis dinding dan Ventilasi dengan Kejadian Infeksi Saluran Pernapasan Akut Pada Balita di Puskesmas Karo Kelurahan Karo Pematangsiantar Tahun 2019.

\section{DAFTAR PUSTAKA}

Depkes RI. 2007. Pengertian ISPA, http://www.google.com.

Depkes RI. 2011. Laporan Riset Kesehatan Dasar Tahun 2012. Jakarta: Kementerian Kesehatan RI

Dinkes Provinsi Sumatera Utara. Profil Kesehatan Sumatera Utara. Diakses dari:

http://profilkesehatansumut2012. pdf.

Asmawati, Indra dan Evi. Hubungan Keadaan Rumah dengan Keluhan ISPA pada Balita di Wilayah Kerja Puskesmas Medan Tuntungan.

Tahun 2010.

Fitria Halim, 2012. Hubungan faktor sanitasi fisik dengan kejadian ISPA pada pekerja di Industri Mebel Dukuh Turejo. didownload dari http://www.jurnalreferensi.com diakses tanggal 15 maret 2019.

Hermansyah, 2015. Faktor resiko terjadinya ISPA pada Balita di Puskesmas Namorambe. 2015.

Heryawan, Iwan. 2011. Pengaruh Sanitasi Rumah terhadap ISPA pada Balita. didownload dari http://www.wordpress.com diakses tanggal 15 maret 2019.

Keman,S, 2011. Kesehatan Perumahan dan Lingkungan Pemukiman: Bagian
Kesehatan Lingkungan, Vol 2 No.1:29-42.

Nurmaini Indra, 2010. Faktor-faktor kesehatan lingkungan yang mempengaruhi kejadian ISPA pada Balita di Perumahan Nasional Mandala. Majalah kedokteran Nusantara. 38 (3): 230-231.

Puskesmas Karo, 2019. Laporan Tahunan Puskesmas Karo. Pematangsiantar 